\title{
If IISGUCDERGI.ORG
}

"IȘ, GÜç̣" ENDÜSTRi iLIȘKiLERi VE INSAN KAYNAKLARI DERGISi

"IS, GUC" INDUSTRIAL RELATIONS AND HUMAN RESOURCES JOURNAL

\section{Kasko Sigortası Tercihinin Konjoint Analizi ile İncelenmesi}

\author{
Zeynep FİLiz \\ Yrd. Doç. Dr., Osmangazi Üniversitesi
}

Murat ŞENGÖZ

Ocak/Jaunary 2010, Cilt/Vol: 12, Say1/Num: 1, Page: 107-121

ISSN: 1303-2860, DOI: 10.4026/1303-2860.2010.140.x

Makalenin on-line kopyasına erişmek için:

http://www.isgucdergi.org/?p=makale\&id=390\&cilt=12\&sayi=1\&yil=2010

To reach the on-line copy of article:

http://www.isguc.org/?p=article\&id=390\&vol=12\&num=1\&year=2010

Makale İçin İletişim/Correspondence to: 
(C) 2000- 2010

"İşGüç" Endüstri İlişkileri ve İnsan Kaynakları Dergisi

"İşGüç" Industrial Relations and Human Resources Journal

Ocak/Jaunary 2010, Cilt/Vol: 12, Say1/Num: 1

ISSN: 1303-2860, DOI: 10.4026/1303-2860.2010.140.x

Editör/Editor-in-Chief

Aşkm Keser (Kocaeli University)

Editör Yardımcıları/Co-Editors

K.Ahmet Sevimli (Uludă̆ University)

Gözde Yılmaz (Kocaeli University)

Uygulama/Design

Yusuf Budak (Kocaeli Universtiy)

\author{
Yayin Kurulu / Publishing Committee \\ Dr.Zerrin Firat (Uludăg University) \\ Doç.Dr.Aşkın Keser (Kocaeli University) \\ Prof.Dr.Ahmet Selamoğlu (Kocaeli University) \\ Yrd.Doç.Dr.Ahmet Sevimli (Uludağ University) \\ Yrd.Doç.Dr.Abdulkadir Şenkal (Kocaeli University) \\ Yrd.Doç.Dr.Gözde Yilmaz (Kocaeli University) \\ Dr.Memet Zencirkıran (Uludă̆ University)
}

Uluslararası Danışma Kurulu / International Advisory Board

Prof.Dr.Ronald Burke (York University-Kanada)

Assoc.Prof.Dr.Glenn Dawes (James Cook University-Avustralya)

Prof.Dr.Jan Dul (Erasmus University-Hollanda)

Prof.Dr.Alev Efendioğlu (University of San Francisco-ABD)

Prof.Dr.Adrian Furnham (University College London-İngiltere)

Prof.Dr.Alan Geare (University of Otago- Yeni Zellanda)

Prof.Dr. Ricky Griffin (TAMU-Texas AEM University-ABD)

Assoc. Prof. Dr. Diana Lipinskiene (Kaunos University-Litvanya)

Prof.Dr.George Manning (Northern Kentucky University-ABD)

Prof. Dr. William (L.) Murray (University of San Francisco-ABD)

Prof.Dr.Mustafa Özbilgin (University of East Anglia-UK)

Assoc. Prof. Owen Stanley (James Cook University-Avustralya)

Prof.Dr.Işık Urla Zeytinoğlu (McMaster University-Kanada)

Danışma Kurulu / National Advisory Board

Prof.Dr.Yusuf Alper (Uludağ University)

Prof.Dr.Veysel Bozkurt (Uludağ University)

Prof.Dr.Toker Dereli (Işık University)

Prof.Dr.Nihat Erdoğmuş (Kocaeli University)

Prof.Dr.Ahmet Makal (Ankara University)

Prof.Dr.Ahmet Selamoğlu (Kocaeli University)

Prof.Dr.Nadir Suğur (Anadolu University)

Prof.Dr.Nursel Telman (Maltepe University)

Prof.Dr.Cavide Uyargil (İstanbul University)

Prof.Dr.Engin Yildırım (Sakarya University)

Doç.Dr.Arzu Wasti (Sabancı University)

Dergide yayınlanan yazılardaki görüşler ve bu konudaki sorumluluk yazarlarma aittir.

Yayınlanan eserlerde yer alan tüm içerik kaynak gösterilmeden kullanılamaz.

All the opinions written in articles are under responsibilities of the outhors.

None of the contents published can't be used without being cited. 


\title{
Kasko Sigortası Tercihinin Konjoint Analizi ile İncelenmesi
}

\author{
Zeynep Fíliz \\ Yrd. Doç. Dr., Osmangazi Üniversitesi
}

Murat ŞENGÖZ

\begin{abstract}
Özet:
Bu çalışmada, pazarlama araştırmalarında firmaların sundukları mal yada hizmetlerin taşıması gereken özelliklerin ve bu özelliklerin önem derecelerinin belirlenmesinde kullanılan Konjoint Analizi incelenmiştir. Bu tekniğ̈in dayandığ kararların alınmasının tek faktöre yada kritere dayanmadığı, aksine bir çok faktörün birlikte dü̧̈ünülerek karar verildiğidir. Uygulamada, İzmir'in Bayındır ilçesindeki otomobil sahibi kişilerin otomobilleri için bir kasko sigortası seçerken en fazla önem verdikleri faktörler ortaya çıkarılmıştır. Elde edilen sonuçlara göre kasko sigortası yaptıracak olanlarn tercihlerinde önem sirasına göre "Kasko Sigorta Şirketinin İsmi" ilk sırada olduğu tespit edilmiş, ikinci sırada tercih olarak karşımıza "Mini Onarım Hizmeti" faktörünün tercih edildiği, üçüncü sırada tercih olarak karşımıza "Araç-Sürücü Temini" faktörü, dördüncü sırada tercih olarak karşımıza "Teminat Kapsamı" faktörü ve beşinci sırada "Ödeme Şekli" faktörünün tercih edildiği görülmü̈ştür. Çalışmanın geneline bakılacak olursa uygulanan modelin kişilerin tercihlerine uygunluğu Pearson'ın R istatistiği 0,991 ve $p=0,0000$ olarak bulunmuştur. Bu da kurulan modelin uygun olduğunu göstermektedir.
\end{abstract}

Anahtar kelimeler: Sigorta, Kasko Sigortası, Konjoint Analizi, Pazarlama, Pazarlama Araştırması

\begin{abstract}
:
In this study, Conjoint Analysis, generally used in marketing research to designate both the features that products or services of the companies must include, and the importance levels of them, is examined. According to this methodology, the purchasing decision of the persons is not only influenced or shaped by just one factor, but also it is a result of a combination of many factors. Application study involving the consumers having automobile in Bayindir, İmir for their preferences to purchase automobile insurance service is investigated. We discovered that, the content of the automobile insurance is the most important variable affecting the consumers preference. The most prefered insurance is "Automobile Insurance Service Name". The secondly important criteria is "Repair" and the thirdly important criteria is "Assistance". The "Guarantee Cover" is determined to be the fourth important criteria. The fifth important criteria is being the service in "Mode of Payment". The Pearson's $R=0,991$ and $p=0,0000$ for the model, so the model is acceptable.
\end{abstract}

Key words: Insurance, Automobile Insurance Service, Conjoint Analysis, Marketing, Marketing Research. 


\section{Gíriş}

Yüksek düzeyde rekabetin yaşandığı günümüz iş hayatında pazarlama, bir işletmenin en önemli fonksiyonlarından biri konumundadır. Zaman içerisinde giderek güçlenen pazarlama fonksiyonu, üretimin önünde yer almaya başlamış, hatta ona yön veren bir etken konumuna gelmiștir. Firmalar "her ne pahasına olursa olsun kar etme" düşüncesini terk ederek kar amacını, tüketicinin tatmin olması amacıyla birleştirme çabasına girişmişlerdir. İşte bu noktada, pazarlama, diğer işletme fonksiyonlarından sıyrılarak önemlilik seviyesinde daha üst noktalara ulaşmıştir.

Sigorta şirketleri gibi hizmet sektöründe yer alan kuruluşlar için başarılı pazarlama çalışmaları, olmazsa olmaz niteliğinde sayılabilir. Türk sigortacılık sektörü üzerine yapılan tartışmalarda vurgulanan en temel sorun, sektörün bir türlü istenilen potansiyeline ulaşamamasıdır. Bu sorun, pek çok değişkeni olan karmaşık bir fonksiyon olmakla beraber pazarlama kavramının tüm bu değişkenler içerisinde oldukça önemli bir yere sahip olduğu ifade edilebilir (Çipil, 2003: 8).

Günümüzde sigortacılık sektörü çok çeşitli türlere ayrılmıştır. Bir çok alanda mümkün olmasına karşın sigorta türlerini can (hayat sigortası, sağlık sigortası, vb.) ve mal (mühendislik sigortaları, yangın sigortası, kasko sigortası, vb.) olarak iki bölüme ayırmak mümkündür. Bu çalışmada sigorta türü olarak, kasko sigortası üzerine bir inceleme yapılmıştır. Mal sigortalarının bir türü olan kasko sigortası; motorlu kara taşıtının sigortalının iradesi dışında hasara uğraması, yanması, çalınması v.b. durumlarda, tazminat ödenmesini sağlamak amacı ile yapılır. Kasko Sigortası karşı araçtaki hasarı değil, sigortalıya ait araçtaki hasarı teminat altına alan bir sigorta türüdür. $\mathrm{Bu}$ sigortanın amac1, sigorta ettirene ait motorlu aracin uğrayacağ ${ }_{1}$ zararları tazmin etmektir.

Bu çalışmada, konjoint analizi yardımıyla kasko sigortalarında şirketler tarafından sunulan farklı hizmetler çerçevesinde tüketici tercihlerini etkileyen faktörlerin önem sırası tespit edilecektir. Konjoint analizi çalışmalarında araştırmacı inceleyeceği ürünün önemli özelliklerini belirlemelidir. Tüketici üründe kendisi için hangi özelliklerin önemli, hangi özelliklerin önemsiz olduğuna karar verir. Tüketiciden, varsayılan ürünlerden hangisini öncelikli olarak tercih edeceğini belirleyen bir sıralama yapması istenir. Konjoint analizinde amaç, kısmi yarar (partworth) olarak bilinen fayda fonksiyonlarınin tahminidir (Erdoğan, 2006: 2).

Çalışmada giriş bölümünü takip eden ikinci bölümde konjoint analizi tanttlacaktır. Üçüncü bölümde ise tüketicilerin kasko sigortası tercihinde göz önünde bulundurdukları kriterler ve bu kriterlerin önem derecelerinin konjoint analizi ile incelenmesine yönelik bir uygulama ele alınmıştır.

\section{KONJOINT ANALIZi}

Olayların analizinde, kısıtlayıcı varsayımlar altında geçerli olan tek değişkenli analizler çoğu durumda yeterli olmamaktadır. Tek değişkenli analizlerle ilgili en önemli kısıt, olaydaki birçok faktörün deneysel olarak kontrol altında tutulması ve her defasinda tek bir faktörün etkisinin incelenmesidir. Günümüzde tek değişkenli istatistiksel analizler yerini, incelenen konu veya olayla ilgili olarak birden fazla özelliğin bir arada ele alınmasına olanak sağlayan çok değişkenli analizlere bırakmıştır. Çok değişkenli analizler, birden çok özelliğin analizi ile ilgilendiğinden uygulamalarda değişik amaçlarla kullanılmaktadır (Aslan, 2006: 12).

Yeni bir ürün üretilmeden ya da var olan ürün güncellenmeden önce ürün planlamacisı veya yöneticiler bu ürüne tüketicilerin nasıl bir tepki göstereceklerini bilmek ister. Bu nedenle üretimden önce bir çalışma yapilarak bu soruya cevap aranır. Bu amaca yönelik olarak üretilecek ürüne ilişkin önemli olabileceği düşünülebilen değişkenler ve bunların düzeyleri belirlenerek, bu değişkenlerin düzeylerinin kombinasyonlarına yer veren özel bir anket düzenlenir. Tüketicilerden bu düzey kombinasyonları için en çok arzu ettiklerinden en az arzu ettiklerine doğru bir tercih sıralaması yapmaları ya da 
tercih puanı vermeleri istenir. Böylece ürüne ilişkin tüketici tercihleri belirlenir; bunun gerçeklenmesinde kullanılan ve yöneticilere bir fikir veren pazarlama araştırması aracı “Konjoint Analizi"dir (Çemrek, 2001: 5).

Konjoint analizi daha çok yeni veya gözden geçirilen bir ürün veya hizmetin niteliklerini belirlemek, fiyatların oluşturulmasına yardımcı olmak, satış veya kullanım düzeyini tahmin etmek ve yeni bir ürün önermek amacı ile kullanılmaktadır. Konjoint analizinin en önemli özelliği ise, nitelikleri nicel olarak karşılaştırmasıdır. Hangi niteliklerin daha önemli olduğunu belirlemenin direkt yolu bireylere sormaktır. Ancak yanitlayıc1ların genellikle tüm niteliklerin de önemli olduğunu belirtmeleri sorun olmaktadır. Örneğin insanlar araba seçerken düşük yakıt tüketimi, spor görünüm, düşük fiyat, vb. özelliklerin olmasını isterler. Bir özelliğin diğerinden vazgeçilecek derecede istenip istenmediği veya bir nitelikten vazgeçilecekse bu niteliğin hangisi olacağını tespit ederek yararlı ve duyarlı bilgiye ulaşılmış olunmaktadır (Yalnız ve Bilen, 1997: 54).

Konjoint analizi, özellikle pazarlamacıların yeni ürünün hangi özelliklere sahip olması ve nasıl fiyatlandırılması gerektiğini elde etmek için kullandığı bir pazar araştırma tekniğidir. Pazar araştırmalarında daha kolay ve daha esnek bir yol olduğu için konjoint analizi popüler olmuştur (Çamlıdere, 2005: 5).

Konjoint analizi potansiyel ürünleri veya hizmetleri sunan önceden tanımlanmış özellik kombinasyonlarının değerlendirilmesi ve tüketici tepkilerini anlamak için uygun bir analizdir. Ayrıca çok gerçekçi bir yaklaşımla analizi yapan kişinin müşteri tercihlerinin bileşimini anlamasını sağlar (Sönmez, 2006: 190).

Konjoint analizinin doğuşu olarak psikolog Luce ve istatistikçi Tukey (1964)'in makalesi olarak görülmektedir. 1970'lerin başında Green ve Rao (1971) ile birlikte Johnson (1974)'nin konjoint analizini pazarlama literatürüne tanitmasindan bu tarafa, konjoint analizi kuramcılar ve alanda araştırma ya- panlar tarafından dikkatli şekilde geliştirilmiştir. Örneğin, Cattin ve Wittink (1982) 1971 ile 1980 yılları arasında 17 şirketin 698 konjoint projesini araştırmalarında kullandıklarını bildirmişlerdir. Wittink ve Cattin (1989), 1981 ile 1985 yılları arasında Amerika'daki 66 şirketin toplam 1062 konjoint projesini gerçekleştirdiklerini bulmuşlardır. Wittink, Vriens ve Burhenne (1994), 1986 ile 1991 yılları arasında Avrupa'da 59 şirketin toplam 956 projeyi yürüttüklerini saptamışlardır. Konjoint araştırmalarında lider olan Sawtooth Software müşteri araştırma şirketi 2004'de, 2003 yılı boyunca 5000 ile 8000 konjoint analizi projesini gerçekleştirdiğini açıklamıştır. Konjoint metodu sadece şirketler için geçerli olmayıp, bugün www.google.com'da 989.000 hit almaktadır (Gustafsson, Herrmann, ve Huber, 2007: 3).

Konjoint analizinin amac1, sinırlı sayıdaki niteliklerin hangi kombinasyonda cevap verenler tarafından tercih edildiğini belirlemektir. Yeni ürünlerin müşteri kabulünü test etmekte ve reklamların etkisini değerlendirmekte sıkça kullanılmaktadır (Çamlıdere, 2005: 6).

Konjoint analizinin avantajları; fiziksel nesnelerin kullanılabilmesi ve bireysel seviyede tercih ölçülebilmesidir. Bununla beraber konjoint analizinin dezavantajları; kombinasyon sayılarının daha fazla özellik eklenmesiyle hızlı artması yüzünden yanlızca sinırlı özellik grubu kullanılabilmesi, bilgi toplama safhasının karmaşık olması ve azaltılmış birbirine bağlı özellikler grubu hakkındaki algılamaları, gerçek özelliklerle ilgili algılamalara çevirecek bir prosedürün olmaması yüzünden ürün konumlandırma araştırması için kullanımının zor olmasıdır (Çamlıdere, 2005: 8).

Konjoint analizi, bazı değişkenlerin birbirine bağlı olduğu bağımlılık analizleri arasında, bir değişkeni bağımlı ve 2 veya daha fazla bağımsız değişkene sahip, çoklu regresyon, varyans, diskrimininant ve kukla değişkenli diskrimininant analizlerinin arasında yer alır. Bu analizlerin birbirinden ayrılmasını sağlayan en önemli özelliklerinden biri, ba- 
ğımlı ve bağımsız değişkenlerin sahip olduğu ölçek tipidir. Buna göre, bağımlı

değişken aralıklı ya da orantılı ölçekle ölçümlendirilmişken, bağımsız değişkenler de aralıklı ya da orantılı ölçekle ölçümlendirilmişse çoklu regresyon analizi, bağımsız değişkenler sınıflayıcı ölçekle ölçümlendirilmişse varyans analizi daha uygun düşmektedir. Diğer yandan, bilindiği gibi niteliksel veri setleri üzerinde sayısal analizlerin uygulanması gerektiğinde kukla değişken kullanımı yoluna gidilmektedir. $\mathrm{Bu}$ amaçla da niteliksel değişkenlere her vasıf için farklı bir sayı getirilmektedir. Bağımlı değişken sınıflayıcı ölçekle ölçümlendirilmişken, bağımsız değişkenler aralıklı ya da orantılı ölçekle ölçümlendirilmişse diskriminant analizi, bağımsız değişkenler s1nıflayıcı ölçekle ölçümlendirilmişse kukla değişkenli diskriminant analizi tercih edilmektedir. Bu analizlerden farklı olarak, bağımlı değişkenin ölçeği sınıflayıcı, sıralayıcı veya aralıklı ölçekli iken, bağımsız değişkenlerin sinıflayıcı veya sıralayıcı olması halinde, konjoint analizi en çok yararlanılan teknik olmaktadır (Sönmez, 2001 :15).

\subsection{Konjoint Analizinin Uygulama Aşamaları}

Bir konjoint analizin uygulanabilmesi ve beklenen yararların optimal olabilmesi için çalışmanın aşağıdaki aşamalarda yürütülmesi gerekir. Bunlar;

- Araştırmanın amacı belirlenerek problemin tanimlanması,

- Pazarda hangi ürünün özelliği veya niteliğinin önemli olduğunun belirlenmesi,

- Tercih fonksiyonunun belirlenmesi,

- Araştırma sorununa hangi konjoint analizi metodunun en uygun olduğunun belirlenmesi,

- Çalıșılan nitelikler arasında ana etki ve ana ilişkilerin hesaplanmasına izin veren deneysel tasarım yaratılması. Birçok konjoint çalışması, sadece niteliğin ana etki ve asıl yararlarına odaklanır. Ama fiyat ve marka gibi nitelikler kullanıldığı zaman nitelikler arasındaki muhtemel ilişkiler de hesaba katılmalıdır,

- Veri derleme tekniğinin seçilmesi ve verilerin derlenmesi,

- Derlenen verilerin analizi için uygun tekniğin seçilmesi ve verilerin analizi,

- Her cevaplayıcı için fayda katsayılarınin hesaplanmas1,

- Sonuçların yorumlanması ve geçerliliklerinin değerlendirilmesi,

- Var olan üründeki değişikliklerin ve yeni ürünün pazara tanıtılmasının etkilerinin tahmin edilmesine yarayacak olan pazar simülasyon modeli yaratılması (Çamlıdere, 2005: 9).

\subsubsection{Problemin Tanımlanması ve Araștırma} Amacinm Belirlenmesi

Tüm araştırma süreçlerinde olduğu gibi konjoint analizinde de ilk adım araştırma probleminin belirlenmesi ve araştırma amacinın belirlenmesidir. Konjoint analizi ile ilgili bir araştırmanın iki amacı vardır. Birincisi, tahmin değişkenleri ve bu değişkenlerin tüketici tercihlerine katkılarının belirlenmesidir. Örneğin; bir uçak bileti alımına havayolları şirketinin (markanın) nasıl bir etkisinin olacağ 1 ya da kredi kartı kullanımında y1llık ücretin ya da kredi limitinin ne kadar etkili olacağı konjoint analizi çerçevesinde araştırılabilir. İkinci amaç ise tüketicinin yargılamalarının ortaya koyduğu özelliklerden oluşan kombinasyonu saptayan geçerli modelin oluşturulmasıdır (Dikici, 2006: 12).

\subsubsection{Tercih Fonksiyonun Belirlenmesi}

Tercih fonksiyonları, ürünün analiz için belirlenen değişkenlerinin düzeyleri ile o değişkenin tercih edilmesi arasındaki ilişkinin yönünü belirlemede kullanılan matematiksel yöntemdir. Tercihlerin ölçülmesi, durum teorisi ve ölçüm modellerinin beklenen değerlerini temel alan bir tüketici araştırma parçasıdır (Çamlıdere, 2005: 15).

Vektör fonksiyonu, ideal nokta fonksiyonu ve parçalı fonksiyon olmak üzere üç tane tercih fonksiyonu vardir. 
Vektör Fonksiyonu : Vektör fonksiyonu sadece sayısal değişkenler ve i'inci değişkenin düzeyleri ile o değişkenin beğenilmesi arasinda doğrusal bir ilişki olduğu düşünüldüğünde kullanılmaktadır. Bu fonksiyon i'inci değişkenin düzeyleri en iyiden en kötüye doğru gittikçe tercihin azalacağı, söz konusu değişkenin düzeyleri en kötüden en iyiye gittikçe tercihin artacağını ifade etmektedir (Green ve Srinivasan, 1978: 109). Eğer değişken düzeyleri kötüden iyiye giderse, o değişkenin tercihinin doğrusal artacağ 1 (Linear More), değişken düzeyleri iyiden kötüye giderse o değişkenin tercihinin doğrusal olarak azalacağ 1 (Linear Less) söylenebilir (Çemrek, 2001: 10). $j^{\prime}$ inci niteliğe ait tercih fonksiyonu;

$S_{j}=\sum_{p=1}^{t} W_{\mathrm{py} \text { ip }} \quad(\mathrm{j}=1, \ldots, \mathrm{m}) \quad(\mathrm{p}=1, \ldots, \mathrm{t})$

Sj: j'inci düzey için yanıtlayıcının tercih puan1

wp : her bir $\mathrm{p}$ niteliğine ait kısmi ağırlıklar

yjp : j'inci profile ait $p$ 'inci nitelik düzeyi ile gösterilir (Saraçlı, 2004: 15).

İdeal Nokta (Quadratic) Fonksiyon : İdeal nokta, karesel bir fonksiyonun temsil ettiği eğrinin tepe noktasına karşılık gelen değişken düzeyidir. İdeal nokta fonksiyonu, ideal bir değişken düzeyi noktasından uzaklaşıldıkça tercih puanında azalmalar olduğunu ifade etmektedir. İdeal nokta fonksiyonu, bir değişkenin optimum ya da ideal düzeyini tanımlayan fonksiyondur ve sürekli, doğrusal olmayan fonksiyona örnektir (Çemrek, 2001: 12).

İdeal nokta fonksiyonu, j. deneme kombinasyonu ve bireyin ideal noktası $\mathrm{Xp}$ arasındaki ağırlıklı uzaklık (dj2) ve tercihler arasındaki ters ilişkiyi ortaya koyar. İdeal nokta fonksiyonu,

$d^{2}{ }_{j}=\sum_{p=1}^{t} W_{\mathrm{p}}\left(\mathrm{y}_{\mathrm{jp}}-\mathrm{x}_{\mathrm{p}}\right)^{2} \quad(\mathrm{j}=1, \ldots, \mathrm{m}) \quad(\mathrm{p}=1, \ldots, \mathrm{t})$

dj 2 : j. deneme kombinasyonuna göre bireyin ideal noktasına (Xp) uzaklığı, yjp : j. deneme kombinasyonu için p özellik düzeyi,

xp : değişken için ideal nokta,

wp : her p özelliğine atanan bireylerin ağırlığ1 ile formüle edilir (Saraçlı, 2004: 15).

Parçalı Fonksiyon : Parçalı fonksiyon, en basit ve en yaygin kullanılan tercih fonksiyonudur. Bu fonksiyonda bir değişken için tercih puanının, bu değişken düzeylerinin fayda katsayısı değerlerinin toplamsal bir fonksiyonu olduğu varsayılır. Genellikle renk, koku gibi değişkenlerin yer aldığ 1 çalişmalarda tercih fonksiyonu olarak parçalı fonksiyon kullanılmaktadır (Çemrek, 2001: 13-14). Parçalı fonksiyon,

$$
S^{2}{ }_{j}=\sum_{p=1}^{t} f_{\mathrm{p}}\left(\mathrm{y}_{\mathrm{jp}}\right) \quad(\mathrm{j}=1, \ldots, \mathrm{m}) \quad(\mathrm{p}=1, \ldots, \mathrm{t})
$$

$\mathrm{Sj}$ : j. deneme kombinasyonuna göre yanitlayıcinin tercih puanı,

fp : j. farklı düzeyde profile sahip her bir kısmi faydanın fonksiyonu,

yjp : j. profile ait p. nitelik düzeyi ile ifade edilir (Saraçlı, 2004: 17).

\subsubsection{Veri Toplama Yöntemleri}

Konjoint analizinde iki tür veri toplama yöntemi vardır. Birincisi her defasında iki faktörün göz önünde bulundurulduğu Trade-Off yöntemi (two factor at a time), ikincisi ise tüm özelliklerin birlikte değerlendirildiği tam kavram (Full Concept) yöntemidir. İlk yöntemin, benzer tabloları bir çok kez cevaplayıcının önüne koyması ve tabloların önemlilik sırasına konmasındaki zorluklar gibi dezavantajları nedeniyle son dönemlerde bu yolla veri toplama terk edilmiştir. Tam kavram yönteminin ise iki dezavantaj1 vardır. Birincisi, özellikler arasındaki ikili yada çoklu etkileşimlerin dikkate alınmaması, diğeri ise olası kombinasyon sayısına sinır getirmesidir. Her biri k düzeyli, n özellik için toplam ürün profili nk' dır. Tüm olası kombinasyonlarının siralanması anket tekniği açısından mümkün olmadığı için her bir özellik ve düzeylerinin seçiminin birbirin- 
den bağımsızlığ 1 varsayımı ile sadece ana özelliklerin dikkate alındığı bir deney düzeni kullanılır (ortogonal düzen). Bu amaçla deney düzenleme tekniklerinden olan kesirli faktöriyel deney tasarımı yardımıyla ana faktörlerin etki derecesini ortaya koyabilecek mümkün olan en az sayıda kombinasyon ile olası durumlar temsil edilir (Gürbüz ve Kayg1siz, 2004: 141-142).

Konjoint analizinde deneme kombinasyonunun genel değerlendirmelerine dayanarak cevaplayıcıların tercih yapılarını açıklayabilmektedir. Bu sırada araştırmacı temel konjoint modeline ilişkin karar vermelidir. Bu kararlar hem deneme kombinasyonunun tasarımı hem de cevaplayıc1 değerlendirmelerinin analizini etkiler. $\mathrm{Bu}$ kararlardan ilki bileşim kuralıdır. Bu bileşim kuralı cevaplayıcının genel değerlerini elde etmek için özelliklerin kısmi yararlarının nasıl birleştirileceğini tanımlar. Ayrıca bileşim kuralının belirtilmesiyle araştırmacı, toplamsal modelin mi yoksa etkileşimli modelin mi kullanılacağını belirlemiş olur. Çok yaygin olarak kullanılan basit bileşim kuralı toplamsal modeldir. Bu modelde cevaplayıc1, özelliklerinin kombinasyonlarının toplam bir değerini elde etmek için, herhangi bir özellik değerinin toplamını hesaplar. Toplamsal model hemen hemen bütün gözlemler için yeterlidir. Araştırmacının temel konjoint modeline ilişkin vereceği ikinci karar, tercih yapısını belirlemektir. Tercih yapısı hem her özelliğin yararını ya da nispi önemini, hem de tercihe duyarlı her özellik içindeki özel düzeylerin etkisini anlatır (Sönmez, 2001:26-27; Saraçl1, 2004: 14).

Veri derleme aşamasında yapılması gereken bir iş, işleyim kombinasyonlarının yanıtlayıcrlara sunumunun belirlenmesidir. Veriler ikili değişken düzey kombinasyonları yaklaşımıyla derleneceği zaman iki değişkenin tüm düzeylerinin farklı kombinasyonları karşılaştırılarak tüketiciler tarafından tercih sıralaması yapilacaksa, bunun için değişkenlerin ikili karşılaştırma tabloları araştırılmalıdır. Ancak veriler tüm değişken düzeylerinin kombinasyonları yaklaşımıyla derlenecekse, yanıtlayıcıların ürün tercihle- rine ilişkin sıralama veya puanlama yaptıkları işleyim kombinasyonları oluşan özel bir anket formundan yararlanılır. Ürün özelliklerini gösteren işleyim kombinasyonlarının yanıtlayıcılara sunulmasında çeşitli sunum şekillerinden yararlanılmaktadır. Sözlü tanımlama, yazılı tanımlama, resimli sunum ve gerçek ürün kullanımı sunulan işleyimlerin yanıtlayıcı tarafından anlașılmasının sağlanmasında kullanılmaktadır. Araștırma problemi tanımlanıp, amaçlar ortaya konulduktan, değişken ve düzeyleri belirlenerek uygun tercih fonksiyonu ve veri derleme tekniğinin seçimi gerçekleştirildikten sonra yapılacak işlem, değişken düzeyleri için fayda katsayılarının kestirimi için uygun tekniğin belirlenmesidir. Fayda katsayıları, yanıtlayıcıların her birinin değişkenlerin hangi düzeylerini daha çok arzu ettiğini belirlemek üzere hesaplanır (Çemrek, 2001: 22).

2.1.4. Değişken Düzeyleri İçin Bireysel Fayda Katsayılarmm Belirlenmesinde Kullanilan Teknikler

Konjoint Analizi'nde değişken düzeylerinin fayda katsayısının belirlenmesi için kullanılan teknikler 3 grupta toplanmaktadır. Bağımlı değişken sıralayıcı ölçekle ölçülmüş ise metrik olmayan teknikler; MANANOVA ve LINMAP teknikleri kullanılır. MANANOVA tekniği parçalı fonksiyon için tercih edilirken, LINMAP ise ideal nokta fonksiyonu için uygun teknik olarak kullanılmaktadır. Bu metotlar içinde Monanova fayda fonksiyonu modeli ile sinırlı iken diğer metotlar hem vektör hem de fayda fonksiyonu modelleri için kullanılabilmektedir. Ayrıca, Linmap ideal nokta modeli için en uygun tekniktir. Linmap'de lineer programlama kullanıldığından diğer metotlardan farklıdır. Lineer programlama ile global optimum parametreler tahmin edilebilmektedir. Bu yöntemler içinde en yaygın olarak kullanılanı Monanova'dır (Dikici, 2006: 30).

\section{2. Çok Sayıda Özellik İçeren Konjoint Analizi}

Şimdiye kadar anlatılan basit konjoint analizi uygulamasında, az sayıda özelliğe sahip 
geleneksel konjoint analizine yer verilmiştir. Ticari çalışmalarda ürünler ya da hizmetler 25 veya 30 özelliğe sahiptir ve tam profil veya trade-off yaklaşımları 6 ile 8 özellik için uygun oldukları için bu durumda idare edilemez bir hal alırlar. Böyle bir durumda konjoint analizinin indirgenmiş şekli özellik sayısını azaltmak için kullanılmalıdır. Bu duruma uygun iki temel yaklaşım, kendi kendini açıklayan ve melez yaklaşımdır. Kendi kendini açıklayan yaklaşımda, cevaplayıcı bir özelliğin her bir düzeyinin değerlendirmesini yapar ve daha sonra genel özelliğin nispi önemliliğine oranlar. Kısmi yararlar iki değerin basit çarpımıyla hesaplanır. Bu yaklaşım genel tercihten ziyade yararın bileşenleri üzerinde yapilan değerlendirmenin bileşimidir. İkinci yaklaşım olan melez yaklaşım, kendi kendine açıklayan yaklaşımı ve kısmi yarar konjoint yaklaşımını içerir. Melez yaklaşım kesirli çok etmenli düzende seçilen daha geniş deneme kombinasyonunun küçük alt grubunun değerlendirilmesiyle birlikte kendi kendini açıklayan yaklaşımın değerlerini kapsar. $\mathrm{Bu}$ yaklaşıma benzer bir yaklaşım Sawtooth Software şirketi tarafından geliştirilen uyarlamacı konjoint analizidir. Uyarlamalı konjoint analizi çok etmenli düzen büyüklüğünü azaltmak için kendi kendine açıklayan yaklaşımın değerlendirmelerini kullanır ve süreci daha uygun hale getirir. Uyarlamalı konjoint analiz özellik sayısı çok fazla olduğundan kendisinde çok şey beklenen bir alternatiftir (Sönmez, 2001: 39).

Uyarlamalı konjoint analizi yaklaşımında veri, araştırılan ürün veya hizmet kategorileri ile ilgili yanıt vericilerin değerlendirme sistemleri ve her bir yanıt vericinin önceki cevaplarına dayanarak bilgisayar yoluyla toplanır. Uyarlamalı konjoint analizi için uyarlanmış görüşmeler, bilgisayar yardımı ile büyük sayıda etken ve düzey içeren çalışmalara olanak sağlar. Uyarlamalı konjoint analizinin en büyük sınırlaması, anketin bilgisayar ortamında yapılması zorunluluğunun olmasıdır. Önceki yıllarda bilgisayarla veri toplamak fazla maliyetli olmakla birlikte, günümüzde bilgisayar teknolojisinin gelişmesiyle daha düşük maliyetli araştır- malara olanak sağlamıştır (Akıncı, Bacanlı ve Kıroğlu, 2007: 2).

\section{UYGULAMA}

Pazarlama, toplumun ve bireyin sosyo-psikolojik yapılarını ilgili bilim dallarından yararlanarak inceleyen ve onların gerçek tutum ve davranışlarını öğrenmeye çalışan, mal ve hizmetlerin tüketicilere ulaştırılmasinda kullanılan yöntemlerden de yararlanarak tüketicilerin istek ve ihtiyaçlarına uygun pazarlama uygulamalarınin bulunmasını sağlayan bir faaliyettir (tr.wikipedia.org).

Modern yaşamın bir parçası olarak, bir otomobile sahip olmak bir ihtiyaç haline gelmiştir. Özellikle otomobil sayısının artmasıyla otomobil sigortalarının önemi artmakta ve dolayısıyla sigortacılığın bu sektöründe rekabetin şiddetlenmesine sebep olmaktadir.

Ülkemizde sigortacılığın en yaygın kullanım şekli, Motorlu Kara Taşıtları Sigortaları'nda görülmektedir. Sigortacılık uygulamasında motorlu kara araçlarının sigortası denilince, aracın kendisinin uğradığı kazalar neticesinde ortaya çıkan hasarların teminat altına alınarak karşılanması anlaşılmaktadır.

Türkiye'de sigorta sektörünün son y1llarda hızlı bir büyüme trendine girmesiyle birlikte çok sayıda yeni şirket kurulmuş ve sektör paylarını artırmak isteyen bu şirketler ciddi bir rekabete girişmişlerdir. Sigorta sektöründeki en büyük rekabette kasko sigortası branşında yaşanmaktadır. Şirketler pazar paylarını artırmak için kasko sigortalarında farklı hizmetler uygulayarak müşteri tercihlerini etkilemeye çalışmaktadır.

Bu çalışmada, konjoint analizi yardımıyla kasko sigortalarında şirketler tarafından sunulan farklı hizmetler çerçevesinde müşteri tercihlerini etkileyen faktörlerin önem sırası tespit edilecektir.

Tüketicilerin tercih ettikleri kasko sigortası tipinin belirlenmesine ilişkin yapılan bu araştırmada bağımlı değişken olarak tercih sıralaması kullanılmıştır. Bu değişken eşit aralıklı ölçekle ölçülmüş olup 1 ile 16 ara- 
sinda değerler almaktadır.

Kasko sigortası tipi tercihini etkileyen bağımsız değişkenler ve düzeyleri belirlenirken sigorta şirketlerinin internet siteleri, sigortac1lıkla ilgili resmi internet siteleri ve uzman kişilerin görüşlerinden yararlanılmıştır. Tüketiciler her zaman en ucuz ve en kaliteli olanı tercih etmesi eğiliminde olacağından dolayı fiyat değişkenine yer verilmemiştir. Belirlenen bağımsız değişkenler ile değişken düzeyleri şöyledir:

Sigorta Şirketi İsmi: Ürettikleri poliçe adetlerine göre pazardaki ilk 3 sigorta şirketi (AXAOYAK, ANADOLU, AKSIGGORTA) değişken düzeyleri olarak belirlenmiş ve diğer sigorta şirketleri de DİĞER adı altında değişken düzeyi olarak belirlenmiştir.

Teminat Kapsamı: Bu değişkenin düzeyleri bazı sigorta şirketlerinde standart olarak olduğu halde bazı şirketlerde ek bir ücret karş1lı̆̆ında olması söz konusu olduğundan dolayı bu değişkene yer verilmiştir. Değişken düzeyleri; kişisel eşya, yurtdışı kapsam ve radyo-teyp olarak belirlenmiştir.

Araç-Sürücü Temini: Aracın bir kazaya karışması sonrasında kişilerin ulaşımı için araç ve sürücü teminin poliçe kapsamında olmasıdır. Bu değişkenin bazı sigorta şirketlerinin poliçelerinde yer almasına karşın bazılarında bulunmamasından dolayı yer almıştır. Değişken düzeyleri olarak da; var veya yok olarak belirlenmiştir.

Ödeme Şekli: Tüketicilerin ödeme güçlerine göre peşin veya kredi kartına taksit olarak değişken düzeyi belirlenmiştir. Taksitli düzeyde vade farkı söz konusu olduğundan tüketicilerin tercihini etkileyebileceği varsayılmıştır.

Mini Onarım Hizmeti: Bazı sigorta şirketlerinin anlaşmalı olduğu servislerde belli limitler dahilinde ücretsiz servis hizmetini poliçelerine dahil etmeleri söz konusudur. Değişken düzeyleri olarak da: var veya yok olarak belirlenmiştir.

Araştırmada kullanılan değişken sayısı 5 ve değişkenlere ilişkin düzey sayısı sırasıyla 4, $3,2,2,2$ 'dir. Düzeylerin tüm olası kombi- nasyonlarını içeren toplam kart sayısı $4^{*} 3 * 2 * 2 * 2=96$ olmaktadır.

Araştırma sırasında 96 kart sağlıklı bir biçimde sıralanmasının mümkün olmadığ 1 için, her bir özellik ve düzeylerinin seçiminin birbirinden bağımsızlığı varsayımı ile sadece ana özelliklerin dikkate alındığ 1 bir deney düzeneği kullanılır (ortogonal düzen).

Bu amaçla deney düzenleme tekniklerinden olan kesirli faktöriyel deney düzeni yard1miyla ana özelliklerin etki derecesini ortaya koyabilecek mümkün olan en az sayıda kombinasyon ile olası durumlar temsil ettirilerek soruna çözüm getirilmiştir. Genelde her biri 3 ve/veya 2 düzeyli 7 özellik içeren çalışmalarda 16-18 kart kullanılırken daha fazla özellik içeren çalışmalarda 20 kart kullanmak alışkanlık haline gelmiştir (Sönmez, 2001: 57).

Konjoint Analizi uygulanırken, ele alınan değişken düzeyleri ile tercih sıralamaları arasındaki ilişkilerin ortaya konulması gerekmektedir. Tercih siralamalariyla aralarinda doğrusal bir artış beklenen değişken " linear more", doğrusal bir azalma beklenen değişken "linear less" ve düzeyleri kategorik olan değişkenler ise "discrete" olarak tanımlanmaktadır (Saraçlı, 2004: 45).

Kurulan modelde, ele alınan faktör ve tercih sıralamaları arasındaki ilişki aşağıdaki gibidir:
Sigorta Şirketi
: Discrete (Kategorik)
Teminat Kapsamı
: Discrete (Kategorik)
Ödeme Şekli
: Discrete (Kategorik)
Mini Onarım Hizmeti : Discrete (Kategorik)
Araç-Sürücü Temini : Discrete (Kategorik)

Burada Şirket İsmi değişkeni ve Teminat Kapsamı değişkenleri sınıflayıcı ölçekle ölçülmüş olduğundan, Ödeme Şekli, Mini Onarım Hizmeti ve Araç-Sürücü Temini değişkenlerinin ise sadece 2 düzeyi olduğundan modelde kategorik olarak tanımlanmıştır.

Değişkenlerin beklenen ilişki doğrultusunda tanımlanmasının nedeni analiz sonrası bek- 
lenen ilişkiden farklı sıralama yapan kişileri ve bu kişilerin hangi faktörlerde farklı s1ralamada bulunduklarını belirlemeye yöneliktir.

Kartların oluşturulması için SPSS 13 paket programinın Syntax menüsünden yararlanarak Tablo 1 elde edilmiştir. Ayrıca 3 tane simülasyon kartı oluşturulmuştur. Araştırmada simülasyon kartlarına yer verilmesi- nin amac1, tekrarlanan satın alma durumları söz konusu olmadığı ve yanitlayıcının tahmin edilen en yüksek yarar skoru ile deneme kombinasyonunu seçtiği varsayımı altından, maksimum yarar model katsayısına bakılarak yapilmıştır.

Araştırmada İzmir'in Bayındır ilçesinde kasko sigortası yaptırmış veya bundan sonra yaptıracak otomobil sahip olan kişilerden

Tablo 1

Ortogonal düzenle elde edilen 16 kart ve 3 simülasyon kartının planı

\begin{tabular}{|c|c|c|c|c|c|c|}
\hline & 艺 & 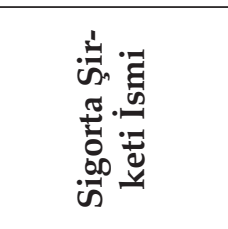 & & 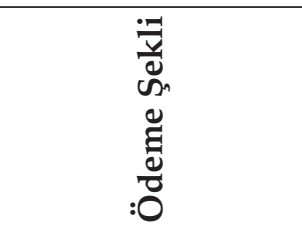 & 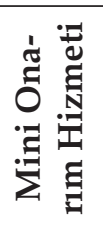 & 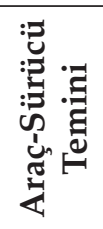 \\
\hline 1 & 1 & AXAOYAK & KIŞ̇ंSEL EŞYALAR & PEŞİंN & VAR & VAR \\
\hline 2 & 2 & AXAOYAK & YURTDIŞI KASKO & $\begin{array}{l}\text { KREDİ KARTINA } \\
\text { TAKSITT }\end{array}$ & YOK & YOK \\
\hline 3 & 3 & DİĞER & KIŞ̇ISEL EŞYALAR & $\begin{array}{c}\text { KREDİ KARTINA } \\
\text { TAKSİT }\end{array}$ & YOK & YOK \\
\hline 4 & 4 & AKSİGORTA & RADYO-TEYP & $\begin{array}{c}\text { KREDİ KARTINA } \\
\text { TAKSITT }\end{array}$ & YOK & VAR \\
\hline 5 & 5 & AKSİGORTA & KİŞISEL EŞYALAR & $\begin{array}{c}\text { KREDİ KARTINA } \\
\text { TAKSIT }\end{array}$ & VAR & YOK \\
\hline 6 & 6 & AXAOYAK & RADYO-TEYP & PEŞİN & YOK & YOK \\
\hline 7 & 7 & ANADOLU & YURTDIŞI KASKO & PEŞİN & VAR & YOK \\
\hline 8 & 8 & ANADOLU & KİŞISEL EŞYALAR & $\begin{array}{c}\text { KREDİ KARTINA } \\
\text { TAKSİT }\end{array}$ & YOK & VAR \\
\hline 9 & 9 & AKSİGORTA & KİŞISEL EŞYALAR & PEŞİंN & VAR & YOK \\
\hline 10 & 10 & DİĞER & KİŞ̇SEL EŞYALAR & PEŞİंN & YOK & YOK \\
\hline 11 & 11 & ANADOLU & KİṠISEL EŞYALAR & PEŞİंN & YOK & VAR \\
\hline 12 & 12 & AXAOYAK & KİŞISEL EŞYALAR & $\begin{array}{c}\text { KREDİ KARTINA } \\
\text { TAKSİT }\end{array}$ & VAR & VAR \\
\hline 13 & 13 & AKSİGORTA & YURTDIŞI KASKO & PEŞİंN & YOK & VAR \\
\hline 14 & 14 & DİĞER & RADYO-TEYP & PEŞİंN & VAR & VAR \\
\hline 15 & 15 & ANADOLU & RADYO-TEYP & $\begin{array}{c}\text { KREDİ KARTINA } \\
\text { TAKSİT }\end{array}$ & VAR & YOK \\
\hline 16 & 16 & DİĞER & YURTDIŞI KASKO & $\begin{array}{c}\text { KREDİ KARTINA } \\
\text { TAKSİT }\end{array}$ & VAR & VAR \\
\hline 1a & 17 & AXAOYAK & RADYO-TEYP & $\begin{array}{c}\text { KREDİ KARTINA } \\
\text { TAKSİT }\end{array}$ & YOK & VAR \\
\hline $2 \mathrm{a}$ & 18 & AKSÍGORTA & KIŞİSEL EŞYALAR & PEŞİN & YOK & VAR \\
\hline $3 a$ & 19 & AXAOYAK & YURTDIŞI KASKO & $\begin{array}{l}\text { KREDİ KARTINA } \\
\text { TAKSIT }\end{array}$ & VAR & VAR \\
\hline
\end{tabular}


rassal olarak seçilen 234 kişiye 16 kartı sıralamaları istenmiştir. Anket uygulanırken değişkenlere ve değişken düzeylerine ilişkin açıklama sözlü olarak ifade edilmiștir. Cevaplayıcılardan oluşturulan 16 kartı kendi tercih önemlerine göre en çok tercih edilenden en az tercih edilene doğru sıralamaları istenmiştir. Böylece değişkenlerin ve düzeylerinin ne anlam ifade ettiğinin cevaplayıc1lar tarafindan daha kolay bir şekilde anlaşılması sağlanmıştır. Bu 16 kartın d1şında kasko sigortalarının özelliklerini içeren ve simulasyon amacıyla çalışmaya katılan 3 kart bulunmaktadır. Bu kartla kişilere sıratılmamıs, cevaplayıcıların diğer 16 kartı önem derecelerine göre siralanması sözlü olarak istenmiştir. Toplanan verilerin SPSS paket programı yardımıyla analizi sonucunda Tablo 2'deki bulgular elde edilmiştir.

\section{Tablo 2}

Tüm yanıtlayıcılar için bireysel fayda katsayıları ile değişkenlerin oransal önem değerleri

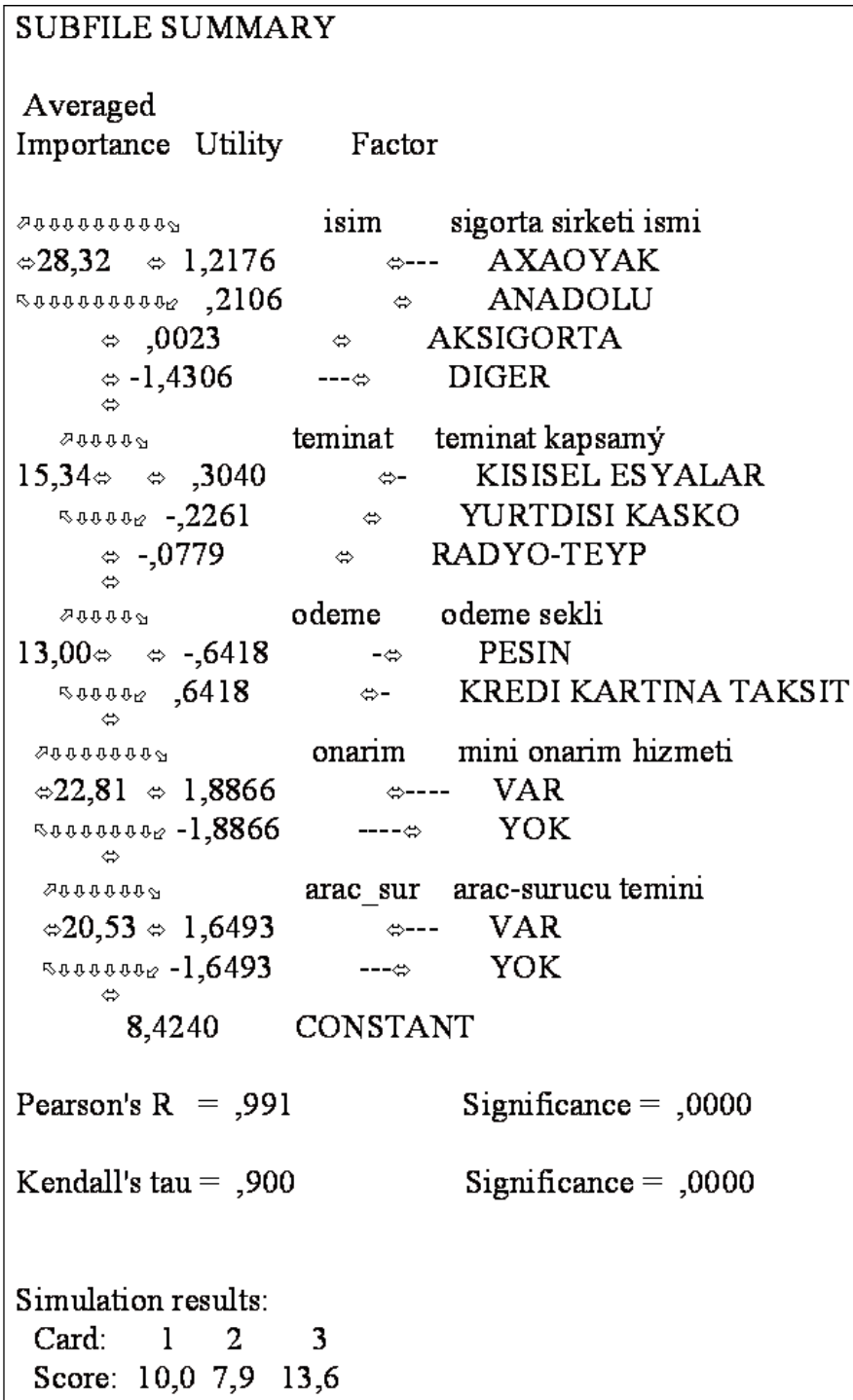


Ankete katılan yanitlayıcıların kasko sigortas1 tercihinde ilk sirada \%28,32 oransal önemle sigorta şirketi ismini göz önünde bulundurduğunu, ikinci sırada \%22,81 oransal önemle mini onarım hizmeti, üçüncü sırada $\% 20,53$ oransal önemle araç-sürücü temini, dördüncü sırada \%15,34 oransal önemle teminat kapsamı ve son olarak \%13 oransal önemle ödeme şekli göz önünde bulundurduklar1 görülmektedir. Bu sıralamada görülmektedir ki, sigorta şirketi ad1 yanıtlayıcıların kasko sigortası tercihinde en önemli rolü oynamaktadır.

Sigorta şirketi ismi değişkeninin düzeyleri için hesaplanan fayda katsayılarına göre en çok tercih edilen sigorta şirketi ismi düzeyi AXAOYAK (fayda katsayısı 1,2176), en az tercih edilen sigorta şirketi ismi düzeyi DİĞER (fayda düzeyi -1,4306) olarak belirlenmiştir.

Teminat kapsamı değişkeninin düzeyleri için hesaplanan fayda katsayılarına göre en çok tercih edilen teminat kapsamı düzeyi KİŞISEL EŞYALAR (fayda katsayısı 0,3040), en az tercih edilen teminat kapsamı düzeyi YURTDIŞI KASKO (fayda düzeyi -0,2261) olarak belirlenmiştir.

Ödeme şekli değişkeninin düzeyleri için hesaplanan fayda katsayılarına göre en çok tercih edilen ödeme şekli düzeyi KREDİ KARTINA TAKSİT (fayda katsayısı 0,6418), en az tercih edilen ödeme şekli düzeyi PEŞİN (fayda düzeyi -0,6418) olarak belirlenmiştir.

Mini onarım hizmeti değişkeninin düzeyleri için hesaplanan fayda katsayılarına göre en çok tercih edilen mini onarım hizmeti düzeyi VAR (fayda katsayısı 1,8866), en az tercih edilen mini onarım hizmeti düzeyi YOK (fayda düzeyi -1,8866) olarak belirlenmiştir.

Araç-sürücü temini değişkeninin düzeyleri için hesaplanan fayda katsayılarına göre en çok tercih edilen araç-sürücü temini düzeyi VAR (fayda katsayıs1 1,6493), en az tercih edilen araç-sürücü temini düzeyi $Y O K$ (fayda düzeyi -1,6493) olarak belirlenmiştir.

Tablo 2'de Pearson'ın R katsayısı belirlenen regresyon modelinin uygunluğunu göstermektedir. Burada Pearson'in R katsayısı 0,991 olarak bulunmuştu ve bu değer $\% 5$ düzeyinde anlamlı çıkmıștır. Buradan belirlenen regresyon modelinin tercih siralarını açıklamada yeterli olduğu söylenebilir.

Tablo 2'deki simülasyon sonucuna göre faydası en yüksek ikinci kart faydası en düşük kart ise üçüncü kart olarak belirlenmiştir. Skor değeri arttıkça tercih sırası düşmektedir. Anket sonucuna göre tercih siralaması Aksigorta, Axaoyak şeklinde olmuştur.

\section{SONUÇ VE ÖNERILER}

Araştırma yoğun zaman tüketimi ve aynı zamanda maliyetli olan bir uğraşıdır. Bu nedenle, üretim programlarına alınılması düşünülen ürünler, çok önceden ve hassas bir şekilde saptanmalıdır. Ancak bu söylenildiği kadar kolay bir iş değildir. Tüketicilerin kullanım alışkanlıklarında, tercihlerinde ortaya çıkan değişmeler ve yeni buluşların ortaya çıkması olasılıkları yapılan çalışmaların yalnızca bu günkü ürün trentlerinin geleceğe uzatılması ile yetinilmeyeceğini açık olarak ortaya koymaktadır.

Günümüzde işletmeler için piyasaya yeni bir ürün çıkarmak ya da var olan bir üründe değişiklik yaparak tekrar piyasaya sürmek, istenmeyen sonuçlar doğurabilmektedir. Birçok büyük işletme bu sorunu göz önünde bulundurarak belirlediği stratejileri bu doğrultuda gözden geçirmekte ve riski mümkün olduğu kadar minimum tutmayı istemektedir. Bu noktada konjoint analizi istenilen amaca hizmet eden önemli istatistiksel tekniklerden biridir.

Konjoint analizi ile etkili bir ürün tasarımı oluşturmak mümkündür. Bu teknik kullanılarak, tüketici için hangi özelliklerin ne düzeyde önemli olduğu, tercih edilip edilmediği gibi sorulara cevap bulunmaktadır. Başarılı bir ürün ve hizmet tasarımı için bu sorulara cevap bulmak gereklidir. Bu çalışmada da kasko sigortaları için bu sorulara cevap bulunmasına çalışılmıştır.

Bu çalışmada elde edilen sonuçlara göre kasko sigortası piyasasında en önemli etke- 
nin sigorta şirketi ismi olduğu görülmüş ve ele alınan şirketler Axaoyak, Anadolu, Aksigorta ve Diğer olarak sıralanmıştır. Türkiye Sigorta ve Reasürans Şirketler Birliği'nin sitesinden elde edilen istatistiklere göre poliçe bazında da şirketlerin pazar paylarının aynı sıralamaya sahip olduğudur. Bu durumda tüketiciler tercihlerinde en büyük etken sigorta şirketinin ismidir. Elde edilen sonuca göre sigorta şirketlerinin tüketicilerin güvenini kazanmaya öncelik vermeleri önerilebilir. Ayrıca sigorta şirketleri teminat kapsamında kişisel eşyaların, kredi kartına taksit ile ödemenin, mini onarım hizmetinin bulunduğu ve kazadan sonra araç-sürücü temininin olduğu poliçeleri göz önünde bulundurmaları önerilir. Böylece pazar paylarını ve gelirlerini arttırabilirler.

Sigorta şirketlerinin pazarlama bölümleri, mevcut hizmetlerini geliştirirken veya tüketicilerin her geçen gün değişen tercih ve isteklerini karşılayabilecek yeni hizmet tasarımlarını hazırlarken çeşitli pazar araştırmaları yapmak zorundadırlar. Bu araştırmalar ancak bilimsel niteliği olan çalışmalarla mümkün olmaktadır. Bilimsel bir çalışmanın süresi, maliyeti, etkinliği ve güvenilir sonuçlara ulaşması, sigorta şirketleri bakımından çok önemlidir. Bu nedenle konjoint analizi pazarlama bölümleri için çok güvenilir bir yol gösterici olmaktadır.

\section{KAYNAKÇA}

Akıncı, E. D., Bacanlı, S., ve Kıroğlu, G., (2007). Uyarlamalı Konjoint Analizi ve İstanbul İndirim Marketleri Üzerine Bir Uygulama, Doğuş Üniversitesi Dergisi 8. Cilt Sayı 1: 1-11, 2007.

Aslan, H., (2006). Sağlık Sigortaları Sektöründe Hizmetlerin Satın Alımında Konjoint Analiz Yaklaşımı, Yüksek Lisans Tezi, Marmara Üniversitesi, İstanbul.

Çamlıdere, Ö., (2005). Konjoint Analizi ve Cep Telefonu Tercihleri Üzerine Bir Uygulama, Yüksek Lisans Tezi, Gazi Üniversitesi, Ankara.

Çemrek, F., (2001). Tüketici Tercihlerinin Belirlenmesinde Kullanılan Konjoint Analizi ve Kredi Kartı Tipi Tercihine İlişkin Bir Uygulama, Yüksek Lisans Tezi, Eskişehir Osmangazi Üniversitesi, Eskişehir.

Çipil, M., (2003). Türk Sigortacılık Sektörünün Pazarlama Karması, Hazine Dergisi Sayı 16: 1-28.

Dikici, T., (2006). Konjoint Analizi ve Tüketicilerin Cep Telefonu Tercihinin Belirlenmesi İle İlgili Bir Uygulama, Yüksek Lisans Tezi, Uludağ Üniversitesi, Bursa.

Erdoğan, C., (2006). Tüketicinin Otomobil Tercihinin Konjoint Analizi İle Belirlenmesi, Yüksek Lisans Tezi, Gazi Üniversitesi, Ankara.

Green, P.E., ve Srinivasan, V., (1978). Conjoint Analysis in Consumer Research :Issues and Outlook, Journal of Consumer Research, 5, 103-123.

Gustafsson, A., Herrmann. A., ve Huber., F., (2007). Conjoint Measurement: Methods and Applications. Fourth Edition, Springer, Berlin, 3-30, New York. 
Gürbüz, H., ve Kayg1sız, Z., (2004). Konjoint Analizi ve Ulaşım Sektör Pazarı Üzerine Bir Çalışma, Süleyman Demirel Üniversitesi İİBF Dergisi C.9, S.1: 139148, Isparta.

Saraçlı, S., (2004). Müşteri Tercihlerinin Araştırılmasında Konjoint Analizi ve Bireysel Emeklilik Tercihi Üzerine Bir Uygulama, Yüksek Lisans Tezi, Anadolu Üniversitesi, Eskişehir.

Sönmez, H., (2001). Konjoint Analizi Tekniğinin Pazarlama Araştırmalarında Kullanım Olanakları ve Bir Uygulama, Doktora Tezi, Anadolu Üniversitesi, Eskişehir.

Sönmez, H., (2006). Müşteri Tercihleri İçin Konjoint Analizi Uygulaması: Ev Bilgisayarı Nasıl Seçilir, Anadolu Üniversitesi Sosyal Bilimler Dergisi 6(2): 185-196.

tr.wikipedia.org, Wikimedia Vakf1, ABD.

Yalnız, A.ve Bilen, L., (1997). Kasko Sigortalarında Konjoint Analizi İle Tüketici Tercihi, Hazine Dergisi Sayı 8, sf. 53-70. 